\title{
EVALUATION OF CYTOTOXICITY OF LEAF AND RHIZOME EXTRACTS OF Alpinia calcarata ROSC. AGAINST HUMAN LUNG NCI-H460 AND CERVICAL HELA CANCER CELL LINES
}

\author{
S. Kathirgamanathar ${ }^{1 *}$, Ahsana Dar ${ }^{2,3}$, Mudassar Azhar ${ }^{3}$, Syeda Roohina Ali3 ${ }^{3}$, M. Iqbal Choudhary ${ }^{2,3}$ and \\ Muhammad Kashif 3
}

${ }^{1}$ Industrial Technology Institute, 363, Bauddhaloka Mawatha, Colombo 7, Sri Lanka.

${ }^{2}$ H.E.J Research Institute of Chemistry, International Center for Chemical and Biological Sciences, University of Karachi, Karachi-75270, Pakistan

${ }^{3}$ Dr. Panjwani Center for Molecular Medicine and Drug Research, International Center for Chemical and Biological Sciences, University of Karachi, Karachi-75270, Pakistan

DO1: http://doi.org/10.4038/s1jb.v2i2.11

\begin{abstract}
The cytotoxicty of Alpinia calcarata rhizome and leaf extracts, fractions and essential oils were evaluated in vitro against human lung NCI-H460 and cervical HeLa cancer cell lines using sulphorhodamine-B assay. Although an array of bioactivities of $A$. calcarata rhizome have been reported previously, no attempt has been made to study the cytotoxicity of rhizome in human lung NCI-H460 and cervical HeLa cancer cell lines. In the present study, both the leaf and rhizome extracts (ethanolic and water) along with their fractions (hexane, dichloromethane, ethylacetate, butanol and water) and essential oils against human lung (NCI-H460) and human cervical (HeLa) cancer cell lines were investigated. Fresh rhizomes and leaves of Alpinia calcarata, collected from Western Province of Sri Lanka were used to obtain the extracts. The essential oils were obtained by hydro-distillation. All the samples were stored at $4{ }^{\circ} \mathrm{C}$. The extracts, fractions and essential oils demonstrated a varying degree of growth inhibition against NCI-H460 cell line. Several fractions showed high growth inhibitory activity (4-94\%). The growth inhibition order was, rhizome water extract $(107.7 \%)<$ rhizome ethanolic extract $(68.2 \%)<$ leaf ethanolic extract $(-25.1 \%)<$ leaf water extract $(-72.3 \%)<$ rhizome oil $(-$ $93.0 \%)<$ leaf oil $(-94.3 \%)$. Dichloromethane fraction of leaf ethanolic extract $(-33.8 \%)$ showed the most promising inhibition at $\mathrm{GI}_{50}: 30.6 \mu \mathrm{g} / \mathrm{mL}$ on NCI-H460. For HeLa cells, the ethyl acetate $(-0.5 \%)$, butanol $(-5.0 \%)$ and aqueous fractions $(-18.1 \%)$ of rhizome water extract showed high growth inhibitions. The potency of the growth inhibition was, rhizome ethanolic extract $(76.56 \%)<$ rhizome water extract $(16.65 \%)<$ leaf oil $(15.88 \%)<$ rhizome oil $(-49.34 \%)$. Efficacy and mechanisms of action in various normal and cancer cell models coupled with bioassay-guided purification to identify active anticancer compound(s) from the crude extract will be useful.
\end{abstract}

Key words: Alpinia calcarata, sulforhodamine-B, HeLa, NCI-H460, cytotoxicity

*Corresponding author: Tel: 0112797323. E-mail: selvaluxmy@iti.lk

(D) http://orcid.org/0000-0003-0695-377X

This is an open-access article distributed under the terms of the Creative Commons Attribution License, which permits unrestricted use, distribution, and reproduction in any medium, provided the original author and source are credited. 


\section{Introduction}

Cancer is a complex group of diseases incorporating physical, environmental, metabolic, chemical and genetic factors. It is one of the leading causes of morbidity and mortality worldwide, accounting for 14 million new cases and over 8 million deaths in 2012. The number of new cases of cancer is expected to reach to 22 million in two decades (WHO, 2014). Due to adverse effects, increasing resistance and unaffordable prices of cancer chemotherapy agents, it is necessary to discover non toxic potential drugs from natural resources for the treatment and prevention of cancer (Demainet al., 2011).

Alpinia calcarata Rosc. (Zingiberaceae) is a rhizomatous perennial herb that is cultivated in tropical countries, including Sri Lanka, India and Malaysia (Jayaweera, 2006). Also known as Heen-araththa (Sinhala); Amkolinji (Tamil); small galangal or snap ginger or cardamom ginger (English); Rasna (Sanskrit); and Kattuchena (Malayalam) (Arambewela et al., 2006), the plant is used as a major constituent of many Ayurvedic formulations, such as Maharasnadhi Quathar (Thabrew et al., 2001), as well as in Sri Lankan indigenous systems of medicine (Arambewela et al., 2006). In Sri Lanka, the rhizomes are commonly used to treat a variety of conditions, such as rheumatoid arthritis (WHO, 2014; Thabrew et al., 2001), polyuria, diabetes, asthma, fungal infections, respiratory ailments, skin diseases, stomach disorders and heart diseases (WHO, 2014). Scientific studies (in vivo) have shown that the rhizomes of $A$. calcarata possess antinociceptive (Arambewela et al., 2004), antioxidant (Arambewela et al., 2005), anti-inflammatory (Arambewela et al., 2006; Arambewela et al., 2012), analgesic, ameliorative effects in alloxaninduced diabetic rats (Navinraj et al., 2011), reproductive competence in male rats (Ratasooriya, W.D., and Jayakody, J.R.A.C, 2006), antifungal (Arambewela et al., 2005; Arambewela et al., 2010), antihelminthic, aphrodisiac, gastroprotective (Arambewela et al., 2009), hypoglycemic, and antihyperglycemic (Arambewela et al., 2009), hypolipidimic and antidiabetic properties (Arambewela et al., 2006). An anti-inflammatory study on carrageenaninduced paw oedema model in rats using $250,500,750$, and $1000 \mathrm{mg} / \mathrm{kg}$ doses of hot water and hot ethanolic extracts of $A$. calcarata showed that $500 \mathrm{mg} / \mathrm{kg}$ hot ethanolic extract induced a higher antiinflammatory effect than the reference drug indomethacin at $4 \mathrm{~h}$ (Arambewela et al., 2006). Alpinia calcarata rhizome contains various elements such as $\mathrm{Cr}$ (1.28 ppm), Mn (2.02 ppm), Fe (55.48 ppm ), Ni (0.13 ppm), Cu (0.96 ppm), Zn (2.03 ppm), Mg (516.4 ppm), Ca (899.7 ppm), Na (417.4 ppm) and K (868.8 ppm). Alpinia calcarata rhizome contains crude fat $(1.68 \%)$, crude protein $(6.39 \%)$, carbohydrate (75.0\%), crude fiber $(7.25 \%)$ and nutritive value (340.8 cal/100 g) (Indrayan et al., 2009).

Gas Chromatographic Mass Spectrometric (GC-MS) analysis of rhizome oil of Alpinia calcarata confirm the presence of $\alpha$ pinene, $\beta$-pinene, $\rho$-cymene, 1,8-cineol, limonene, camphene, camphor, $\alpha$ terpineol, $\gamma$-muurolene, caratol, fenchyl acetate, $\alpha$-eudesmol and trace amount of fenchol, fenchone, linalool, $\alpha$-cadinene and $\beta$-caryophyllene. The leaf oil is reported to have $\alpha$-pinene, $\beta$-pinene, $\rho$ cymene, 1,8-cineol, limonene, camphene, camphor, $\alpha$-terpineol, $\quad \gamma$-muurolene, caratol, $\alpha$-eudesmol, $\alpha$-cadinene and $\beta$ caryophyllene and trace amounts of 
fenchone. Root oil also contains similar compounds as rhizome and leaf oils (Kathirgamanathar, 2011).

Two bis-labdanic diterpenoids, named calcaratarins D \& E, isolated from the rhizome of Alpinia calcarata grown in China, were found to have cytotoxic activity against human $\mathrm{KB}$ cells (Ling-Yi LY Kong et al., 2002). The ethanol extract of rhizome at $8 \mathrm{mg} / \mathrm{kg} /$ day significantly reduced Ehrlich ascites carcinoma in Swiss Albino mice (Perveen et al., 2012).
(K562) (Chauhan et al., 2014) and gastric (AGS) (Hadjzadeh et al., 2014) cancer cell lines, while galangin, isolated from $A$. galanga, showed strong anticancer, antioxidant, antimutagenic and antiinflammatory activities (Pandey Govind, 2011). Pinostrobin chalcone, isolated from the ethylacetate extract of $A$. mutica, showed a remarkable cytotoxic activity against the human cancer cells named as KB, MCF-7 and Caski cells with $\mathrm{IC}_{50}$ values of 6.2, 7.3 and $7.7 \mu \mathrm{g} / \mathrm{mL}$, respectively (Sri Nurestri et al., 2011).<smiles>C=CC(OC(C)=O)c1ccc(OC(C)=O)cc1</smiles>

Acetoxy chavicol acetate Galangin Pinostrobinone

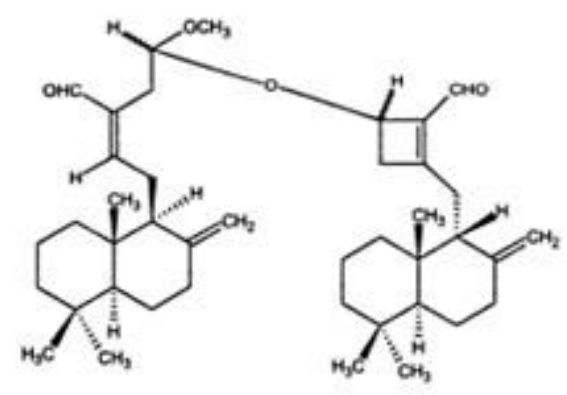

Calcaratarin D

Figure 1. Anticancer active compounds from Alpinia species (Sri Nurestri et al., 2011)

Acetoxy chavicol acetate, isolated from the rhizomes of $A$. galanga, showed significant anticancer activities against breast (MCF-7 and MCF-7/ADR) (Samarghandian et al., 2014), lung (H522), prostate (DU145), leukemia
n-Hexane and dichloromethane extracts of leaves and rhizomes of $A$. scabra grown in Malaysia were screened for cytotoxic effect against SKOV-3 and MCF-7 cells. The n-hexane and dichloromethane extracts of rhizome showed a high 
cytotoxic effect against both cells with $\mathrm{IC}_{50}$ values of 8.3 and $7.0 \mu \mathrm{g} / \mathrm{mL}$, respectively (Ibrahim et al., 2010).

Although an array of bioactivities of $A$. calcarata rhizome have been reported previously (Arambewela et al., 2004), no attempt has been made to study the cytotoxic activity of the rhizome and leaf in human lung NCI-H460 and cervical HeLa cancer cell lines. Additionally, in previous studies, only the rhizome extracts were studied. However, in present study, A. calcarata rhizome and leaf extracts (aqueous and ethanolic) along with their fractions (hexane, dichloromethane, ethyl acetate, butanol and water) and essential oils against human lung (NCI-H460) and human cervical (HeLa) cancer cell lines were investigated.

\section{Material and Methods}

\subsection{Plant collection}

A. calcarata rhizomes and leaves were collected from a home garden in Western Province, Sri Lanka, during July 2011. The plant was identified by comparing with an authenticated sample that was grown in Industrial Technology Institute and deposited in Royal Botanical Gardens, Peradeniya, Sri Lanka (Voucher specimen number AC 01).

\subsection{Chemicals and cancer cell lines}

Human lung NCI-H460 and human cervical HeLa cancer cell lines were obtained from the National Cancer Institute, USA. FBS was purchased from Gibco and sulforhodamine-B from MP Biomedicals, USA. All the other chemicals were purchased from Sigma, USA.
2.3 Extraction, fractionation and distillation of oil

The collected plant material was washed under running water, cut into small pieces and shade dried for 10 days. The dried samples were extracted with water (refluxing for $5 \mathrm{~h}$ ) and $70 \%$ ethanol (Soxhlet extraction for $6 \mathrm{~h}$ ) separately. The water extract was evaporated under reduced pressure $\left(150 \mathrm{mbar}\right.$ at $\left.<50{ }^{\circ} \mathrm{C}\right)$ in a rotary evaporator, and freeze dried. The dried crude extracts were fractionated with hexane, dichloromethane, ethyl acetate, butanol and water. For the extraction of oils, dried rhizomes and leaves (500 g each) were subjected to hydro-distillation using Clevenger apparatus for $6 \mathrm{~h}$. The oils were stored at $4{ }^{\circ} \mathrm{C}$ in air-tight containers until used for the cytotoxicity test.

\subsection{Cytotoxic activity test}

The cytotoxic activity was evaluated by sulphorhodamine-B assay (Monk et al., 1991). Alpinia calcarata extracts, oils and fractions, were evaluated against human lung NCI-H460 and human cervical HeLa cancer cell lines. Cells were plated in 96microwell plates (NCI-H460: 7500 cells/well; HeLa: 10,000 cells/well) and incubated at $37^{\circ} \mathrm{C}$ for $24 \mathrm{~h}$ in a humidified $5 \% \mathrm{CO}_{2}$ incubator. Doxorubicin, an anticancer drug was used as the standard. Stock solutions of ethanolic and water extracts of $A$. calcarata $(40 \mathrm{mg} / \mathrm{mL})$, fractions $(20 \mathrm{mg} / \mathrm{mL})$ and positive control doxorubicin $(1 \quad \mu \mathrm{M})$ were prepared in DMSO. For the initial screening, $100 \mu \mathrm{L}$ of ethanolic and water extracts and the oils derived from rhizomes, and leaves $(250 \mu \mathrm{g} / \mathrm{mL})$ and the fractions $(100 \mu \mathrm{g} / \mathrm{mL})$ were added into each well and incubated. Fifty microliter of $50 \%$ cold trichloroacetic acid (TCA) was added in the wells and left for $30 \mathrm{~min}$ at room temperature. The wells were then washed with distilled 
water and dried overnight. Sulforhodamine-B (SRB) solution (100 $\mu \mathrm{L}, 0.4 \% \mathrm{wt} / \mathrm{vol}$ in $1 \%$ acetic acid) was added. After $30 \mathrm{~min}$, the unbound SRB was removed by washing with $1 \%$ acetic acid, and air-dried at room temperature. The protein bound stain was solubilized with $10 \mathrm{mM}$ Tris-base $(\mathrm{pH}$ 10.2), the plates were shaken for 5 min by using a plate shaker and the absorbance was measured at $515 \mathrm{~nm}$ using SpectraMax Plus $^{384}$ microplate reader. The absorbance of the appropriate blanks, including sample blanks, and control (without plant sample), was used to calculate the percentage net growth (\%NG), and the cytotoxicity of the extracts and fractions. $A$. calcarata extracts and the fractions were further evaluated at various concentrations (extracts: 15.62, 31.25, 62.5, 125 and 250 $\mu \mathrm{g} / \mathrm{mL}$; fractions: $6.25,12.5,25,50$ and $100 \mu \mathrm{g} / \mathrm{mL}$ ) to study the dose response. The growth inhibition and cytotoxicity of extracts and fractions was represented as GI50 ( $\mu \mathrm{g} / \mathrm{mL})$ values. The standard drug doxorubicin demonstrated the $\mathrm{GI}_{50}(0.07$ $\pm 0.00 \mu \mathrm{g} / \mathrm{mL})$ and $\mathrm{LC}_{50}(0.86 \pm 0.00$ $\mu \mathrm{g} / \mathrm{mL})$. All cytotoxic activity was assessed at $12 \mathrm{~h}$ following the treatment. The sulforhodamine-B assay was used to quantify the cytotoxic effects.

\subsection{Gas chromatography- Mass} spectrometric analysis

Oil samples (rhizome oil, leaf oil and the hexane fraction of leaf ethanolic extract: $0.5 \mu \mathrm{L}$ each) were injected into an Agilent 7890A/7000AGC triple quadrupole mass spectrometer system (GC/QQQ) for identification of compounds using 1:60 split injection ratio. A HP-5MS fused silica capillary column of $30 \mathrm{~m}$ length, $0.25 \mathrm{~mm}$ inner diameter and $0.25 \mu \mathrm{m}$ film thickness (J\&W Scientific, USA) was used.
The initial oven temperature was $40{ }^{\circ} \mathrm{C}$ for $5 \mathrm{~min}$ ramped to $280{ }^{\circ} \mathrm{C}$ at $10^{\circ} \mathrm{C} / \mathrm{min}$, and held there for $5 \mathrm{~min}$. The linear velocity of the carrier gas (Helium) was constant at $40 \mathrm{~cm} / \mathrm{s}$. The inlet temperature was $250{ }^{\circ} \mathrm{C}$, transfer line temperature was $250{ }^{\circ} \mathrm{C}$ and EI ionization source temperature was $230{ }^{\circ} \mathrm{C}$. Mass spectra were acquired using full scan monitoring mode with a mass range of 50-500 m/z. Data Analysis was done by using Agilent Mass Hunter software version B.04.00 and National Institute of Standards and Technology (NIST) Data base Library 2010.

\subsection{Statistical analysis}

Results are presented as Mean \pm Standard Error. Significance of differences between groups was assessed with use of one way ANOVA.

\section{Results}

Hexane, dichloromethane, ethylacetate, butanol and aqueous fractions of $A$. calcarata ethanolic and water extracts as well as the oils derived from rhizomes and leaves demonstrated a varying level of growth inhibition (\%NG) against lung cancer cell line NCI-H460 (Figure 1, Table 1 and 2).

The butanol fraction from both rhizome ethanolic extract and rhizome water extract, dichloromethane and ethylacetate fractions of the leaf ethanolic extract, and the hexane, dichloromethane, ethylacetate, butanol and aqueous fractions of $A$. calcarata ethanolic and water extracts, as well as the oils derived from rhizomes and leaves demonstrated a varying level of growth inhibition (\%NG) against lung cancer cell line NCI-H460 (Fig. 1, Table1 and 2). The butanol 
fraction from both rhizome ethanolic extract and rhizome water extract, dichloromethane and ethylacetate fractions of the leaf ethanolic extract and the hexane and dichloromethane fractions of the leaf water extract showed a higher inhibitory activity ranging between 4-94\%. Results revealed differences among the extracts and fractions for growth inhibition. Leaf ethanolic extract showed a high growth inhibition as compared to the leaf water extract and the oils.

The growth inhibition potency order was rhizome water extract $(107.7 \%)<$ rhizome ethanolic extract $(68.2 \%)<$ leaf ethanolic extract $(-25.1 \%)<$ leaf water extract $(-72.3 \%)<$ rhizome oil $(-93.0 \%)<$ leaf oil $(-94.3 \%)$. Among all the fractions tested, the dichloromethane fraction of leaf ethanolic extract (\%NG: $-33.8 \%$; cytotoxicity- $\mathrm{GI}_{50}: 30.6 \mu \mathrm{g} / \mathrm{mL}$ ) was the most promising.
For the HeLa cell line, the ethylacetate and aqueous fractions of rhizome ethanolic extract showed significantly moderate growth inhibition while ethylacetate, butanol and aqueous fractions of rhizome water extract showed a high growth inhibition (Table 3). Rhizome oil showed highly potent growth inhibition on HeLa cells as compared to leaf oil. Among the extracts and oils tested, the potency of the growth inhibition was ranked as rhizome ethanolic extract $<$ rhizome water extract $<$ leaf oil < rhizome oil (Table 3).

\section{Discussion}

The major aim of this study was to identify potential anticancer extracts that were effective, even at low doses. In order to achieve this aim, the maximum test concentration was set at $100 \mu \mathrm{g} / \mathrm{mL}$ as the criteria for identifying extracts with potent activity within the range.

Table 1. Cytotoxicity dose response of A. calcarata extracts and oils on human lung cancer cell line NCI-H460

\begin{tabular}{lcccccc}
\hline Extracts & \multicolumn{5}{c}{ Concentration $(\mu \mathrm{g} / \mathbf{m L})$} & GI $_{\mathbf{5 0}}(\boldsymbol{\mu g} / \mathbf{m L})$ \\
\cline { 2 - 6 } & $\mathbf{1 5 . 6 2}$ & $\mathbf{3 1 . 2 5}$ & $\mathbf{6 2 . 5}$ & $\mathbf{1 2 5}$ & $\mathbf{2 5 0}$ & \\
\hline $\begin{array}{l}\text { Rhizome } \\
\text { oil }\end{array}$ & $103.68 \pm 0.98$ & $111.74 \pm 0.75$ & $102.33 \pm 8.53$ & $5.46 \pm 2.43$ & $-2.81 \pm 14.92$ & $111.23 \pm 7.05$ \\
\hline Leaf oil & $108.9 \pm 4.89$ & $101.44 \pm 1.88$ & $107.11 \pm 8.57$ & $64.74 \pm 8.09$ & $-80.09 \pm 2.39$ & $109.61 \pm 1.40$ \\
\hline $\begin{array}{l}\text { Leaf } \\
\text { ethanolic }\end{array}$ & $49.24 \pm 16.61$ & $25.77 \pm 5.70$ & $39.38 \pm 1.20$ & $32.48 \pm 0.79$ & $-65.01 \pm 3.84$ & $22.82 \pm 10.91$ \\
extract & & & & & & \\
\hline $\begin{array}{l}\text { Leaf water } \\
\text { extract }\end{array}$ & $105.60 \pm 1.84$ & $106.83 \pm 8.02$ & $111.13 \pm 6.02$ & $105.50 \pm 4.50$ & $35.76 \pm 1.52$ & $239.47 \pm 1.50$ \\
\hline
\end{tabular}

represented as mean \pm S.E of three independent experiments in triplicate $(n=3) ; \mathrm{GI}_{50}-\mathrm{Grow}_{\mathrm{th}}$ inhibition at $50 \%$ concentration of extract or oil. 


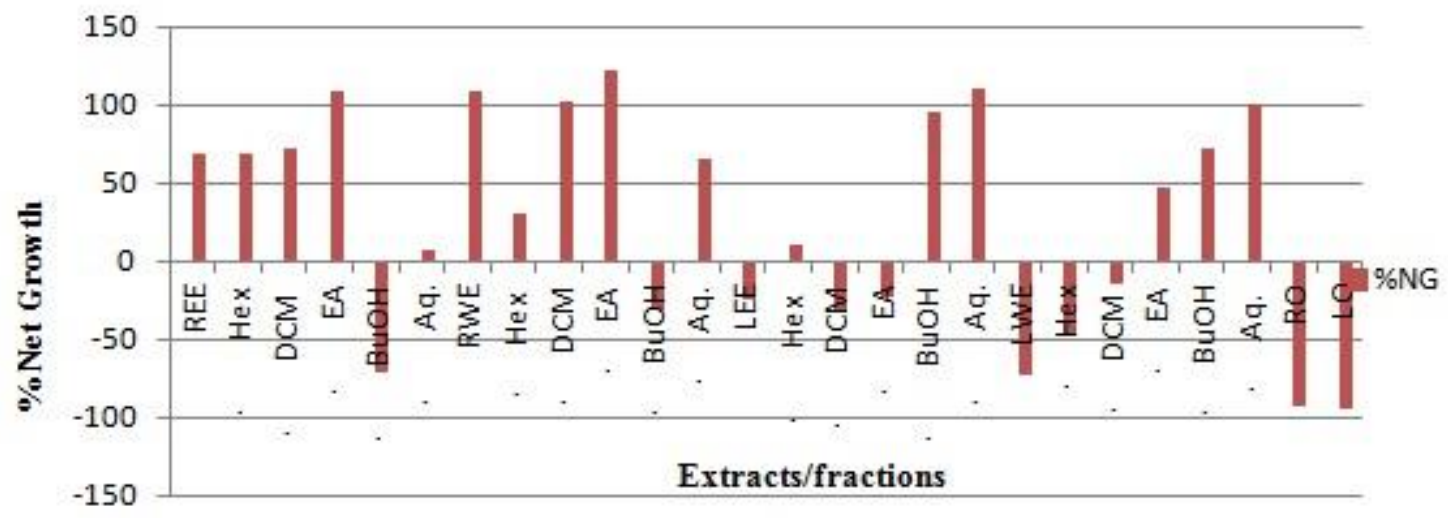

Figure 1. Cytotoxic effects of $A$. calcarata extracts, fractions and oils derived from rhizomes and leaves on lung cancer cell line NCI-H460. REE-Rhizome Ethanolic Extract; Hex-Hexane fraction; DCM-Dichloromethane fraction; EA-Ethylacetate fraction; $\mathrm{BuOH}-$ Butanol fraction; Aq.-Aqueous fraction; RWE-Rhizome Water Extract; LEE-Leaf Ethanolic extract; LWE-Leaf Water Extract; RO-Rhizome Oil; LO-Leaf Oil.

Table 2. Cytotoxicity dose response of solvent diluted fractions of extracts of $A$. calcarata on human lung cancer cell line NCI-H460

\begin{tabular}{|c|c|c|c|c|c|c|}
\hline \multirow[t]{2}{*}{ Fractions } & \multicolumn{5}{|c|}{ Concentration $(\mu \mathrm{g} / \mathrm{mL})$} & \multirow{2}{*}{$\begin{array}{c}\mathbf{G I}_{50} \\
(\mu \mathrm{g} / \mathrm{mL})\end{array}$} \\
\hline & 6.25 & 12.5 & 25 & 50 & 100 & \\
\hline $\begin{array}{l}\text { DCM } \\
\text { fraction } \\
\text { of LEE }\end{array}$ & $70.98 \pm 6.0$ & $51.00 \pm 7.2$ & $26.63 \pm 0.9$ & $16.83 \pm 1.4$ & $-5.66 \pm 12.7$ & $30.61 \pm 2.9$ \\
\hline $\begin{array}{l}\text { EA } \\
\text { fraction } \\
\text { of LEE }\end{array}$ & $66.01 \pm 3.5$ & $39.32 \pm 3.4$ & $13.01 \pm 5.5$ & $15.62 \pm 0.8$ & $-58.23 \pm 8.2$ & $2351 \pm 1.9$ \\
\hline $\begin{array}{l}\text { BuOH } \\
\text { fraction } \\
\text { of REE }\end{array}$ & $88.10 \pm 5.1$ & $86.78 \pm 9.4$ & $88.31 \pm 3.0$ & $73.12 \pm 9.0$ & $48.95 \pm 4.7$ & $102.42 \pm 5.4$ \\
\hline $\begin{array}{l}\text { BuOH } \\
\text { fraction } \\
\text { of RWE }\end{array}$ & $80.93 \pm 2.0$ & $73.28 \pm 7.5$ & $74.91 \pm 1.5$ & $78.97 \pm 4.2$ & $68.95 \pm 4.0$ & $422.81 \pm 97.4$ \\
\hline
\end{tabular}

Data represented as mean \pm SE of three independent experiments in triplicate $(\mathrm{n}=3)$. $\mathrm{GI}_{50}-$ Growth inhibition at 50\% concentration of extract or fraction

LEE-Leaf Ethanolic Extract; REE-Rhizome Ethanolic Extract; Hex-Hexane fraction; DCMDichloromethane fraction; EA-Ethylacetate fraction; BuOH-Butanol fraction; Aq.-Aqueous fraction; RWE-Rhizome Water Extract 
Table 3. Effect of $A$. calcarata rhizome and leaf ethanolic and water extract, fractions and oils on cervical cancer cell line HeLa

\begin{tabular}{lll}
\hline \multicolumn{1}{c}{ Extracts and Fractions } & Conc. $(\mu \mathrm{g} / \mathbf{m L})$ & \%NG \\
\hline $\begin{array}{l}\text { Rhizome ethanolic extract } \\
\text { Fractions }\end{array}$ & 250 & $76.56 \pm 13.12^{\mathrm{a}}$ \\
$\begin{array}{l}\text { - Ethyl acetate } \\
\text { - Butanol }\end{array}$ & 100 & $10.36 \pm 4.46^{\mathrm{b}}$ \\
- Aqueous & 100 & $41.66 \pm 7.67^{\mathrm{b}}$ \\
Rhizome water extract & 100 & $22.98 \pm 15.78^{\mathrm{b}}$ \\
- Ethyl acetate & & $16.65 \pm 7.35^{\mathrm{a}}$ \\
- Butanol & 100 & $-0.57 \pm 6.14^{\mathrm{ba}}$ \\
- Aqueous & 100 & $-5.04 \pm 8.14^{\mathrm{ba}}$ \\
\hline Rhizome oil & 100 & $-18.14 \pm 1.85^{\mathrm{b}}$ \\
Leaf oil & 250 & $-49.34 \pm 16.04^{\mathrm{b}}$ \\
\hline
\end{tabular}

Data represented as mean \pm SE $(n=3)$; \%Net growth superscripted by different letters is significantly different at $\mathrm{p}<0.05$.

Using this criterion, extracts with less than $50 \%$ inhibitory activity within the test range were excluded from further screening.

Although such extracts may likely demonstrate cytotoxicity at higher concentrations, the focus in this study was limited to plant extracts that caused substantial growth inhibition in a given cell line within the test concentration of < $100 \mu \mathrm{g} / \mathrm{mL}$. The assumption was that such activity in the plants crude nature would be indicative of even greater inhibitory effects in the purified state. For initial identification of extracts with activity, the effects were evaluated against human lung NCI-H460 and human cervical HeLa cancer cell lines.

\section{Conclusion}

This study has demonstrated the screening process of bioactive extracts with anticancer activity by eliminating the less active ones on the basis of cytotoxicity that takes effective dosage into consideration. Results obtained from extracts screened showed that all extracts exhibited a promising cytotoxic activity against human lung cancer cell line. Among the active extracts and fractions, the fraction with the highest anticancer activity was from the DCM fraction of leaf ethanolic extract, which was found to possess a potent anti-cancer activity with GI50: $\quad 30.6 \mu \mathrm{g} / \mathrm{mL}$. Efficacy and mechanisms of action in various normal and cancer cell models coupled with bioassay-guided purification to identify active anticancer compound(s) from the crude extract will be useful. 


\section{Acknowledgements}

Financial assistance from NAM S\&T Centre, India and H.E.J International Centre for Chemical and Biological Sciences (ICCBS), University of Karachi, Pakistan Fellowship is kindly acknowledged.

\section{References}

World Health Organization. (2014) Cancer

Fact Sheet. http://www.who.int/mediacentre/factsheets /fs297/en/, Retrieved on16thJanuary 2015.

Demain, A., Vaishnav, P. (2011) Natural products for cancer chemotherapy, Microbial Biotechnology 4(6): 687-699.

Jayaweera, D., Senaratne, L. (2006) Medicinal Plants Used in Ceylon - Part 5, National Science Foundation, p. 212-213.

Arambewela L, Alagiyawanna S, Edited by Dilmani Warnasuriya. (2006) Alpinia calcarata: Sri Lankan Medicinal Plant Monographs and Analysis, National Science Foundation 7: 1-27.

Thabrew, I et al., (2001) Antioxidant potential of two polyherbal preparations used in Ayurveda for the treatment of rheumatoid arthritis, Journal of Ethnopharmacology 76(3): 285-291.

Arambewela, L et al., (2004) Antinociceptive activities of aqueous and ethanolic extracts of Alpinia calcarata rhizomes in rats, Journal of Ethnopharmacology 95(2-3): 311-316.

Arambewela, L., Arawwawala, L. (2005) Antioxidant activities of ethanolic and hot aqueous extracts of Alpinia calcarata rhizomes, Australian Journal of Medical Herbalism 17(3): 91-94.

Arawwawala L et al., (2009) Effect of Alpinia calcarata rhizomes on ethanol-induced gastric ulcers in rats. Pharmacognosy Magazine 4(5): 226-231.
Arawwawala L et al., (2009) Hypoglycemic and antihyperglycemic activities of the aqueous and the ethanolic extracts of Alpinia calcarata rhizomes in rats, Pharmacognosy Magazine 5(20): 412-418.

Arawwawala L et al., (2010) Antifungal and antioxidant properties of essential oil of Alpinia calcarata rhizomes, Journal of Ayurveda and Integrative Medicine 1(3): 199202.

Ratasooriya, W.D., and Jayakody, J.R.A.C. (2006) Effects of aqueous extract of Alpinia calcarata rhizomes on reproductive competence of male rats, Acta Biologica Hungarica 57(1), pp.23-35.

Navinraj, S.N et al., (2011) Ameliorative effects of Alpinia calcarata in Alloxan-Induced Diabetic rats, Digest Journal of Nanomaterials and Biostructures 6(3), p.991-997.

Arawwawala, L et al., (2012) Alpinia calcarata Roscoe: A potent anti-inflammatory agent. Journal of Ethnopharmacology 139(3): 889892.

Indrayan, A.K et al., (2009) Nutritive values of some indigenous plant rhizome resembling ginger. Natural Products Radiance 8(5): 507513.

Ling-Yi LY Kong et al., (2002) Newcytotoxic bis-labdanic diterpenoids from Alpinia calcarata, Planta Medica; 68(9): 813-7.

Kathirgamanathar, S. (2011) Progress report, HEJ, International Centre for Chemical and Biological Sciences, University of Karachi, Pakistan, 24 p.

Perveen, R et al., (2012) Preventive effect of ethanol extract of Alpinia calcarata Rosc on Ehrlich's ascitic carcinoma cell induced malignant ascites in mice, Asian Pacific Journal of Tropical Medicine 5(2): 121-5.

Samarghandian, S et al., (2014) Antiproliferative activity and induction of apoptotic by ethanolic extract of Alpinia 
galanga rhizhome in human breast carcinoma cell line, BMC Complementary and Alternative Medicine, 14: 192.

Hadjzadeh M-A-R et al., (2014) The Effects of Aqueous Extract of Alpinia galanga on Gastric Cancer Cells (AGS) and L929 Cells in Vitro, Iranian Journal of Cancer Prevention 7(3): 142-146.

Pandey, Govind. (2011) Some important anticancer herbs: A review, International Research Journal of Pharmacy 2(7): 45-52.

Sri Nurestri et al., (2011) Phytochemical and Cytotoxic Investigations of Alpinia mutica Rhizomes, Molecules 16: 583-589.

Ibrahim, $\mathrm{H}$ et al., (2010) Cytotoxic activity of leaf and rhizome extracts of Alpinia scabra (Blume) Náves, a wild ginger from Peninsular Malaysia, African Journal of Pharmacy and Pharmacology 4(10): 708-711.

Chauhan, V.S et al., (2014) Phytochemical Investigation and Cytotoxic Activity of Methanolic Extract of Alpinia galanga, International Journal of Applied Biology and Pharmaceutical Technology 5(3): 186-189.

Monks, A et al.,(1991). Feasibility of a highflux anticancer drug screen using a diverse panel of cultured human tumor cell lines, Journal of the National Cancer Institute 83(11): 757-66. 